\title{
FORENZNÍ PSYCHOLOGIE V ČESKÉ PSYCHOLOGICKÉ LITERATUŘE - NÁHLED DO HISTORIE DO ZAČÁTKU DRUHÉ SVĚTOVÉ VÁLKY
}

\author{
Veronika A. Polišenská
}

\begin{abstract}
Abstrakt
Historie forenzní psychologie v Čechách a na Slovensku je popsána v řadě psychologických a kriminologických publikacích obvykle v rámci úvodních kapitol. Tyto texty se však liší v různých aspektech: vymezení začátku forenzní psychologie či popsání historického vývoje forenzní psychologie. Cílem tohoto článku je nahlédnout do historie forenzní psychologie do začátku druhé světové války a poukázat na to, jak je prezentována v české a slovenské psychologické literatuře. Na základě této exkurze byly také doplněny různé informace dohledáním primárních zdrojů.
\end{abstract}

Klíčová slova: forenzní psychologie, historie, zdroje

THE FORENSIC PSYCHOLOGY IN CZECH PSYCHOLOGICAL LITERATURE - PEEK INTO HISTORY UNTIL SECOND WORLD WAR

\begin{abstract}
The history of forensic psychology in Czech Republic and Slovakia is described in many psychological or criminological publications usually in the introductory chapters. These texts, however, differ in different aspects: definition of the beginning of forensic psychology and the description of the historical development of forensic psychology. The aim of this article is to present how forensic psychology's history till the beginning of WWII is represented in Czech and Slovak psychological literature, and further to fill in missing information by searching for primary sources.
\end{abstract}

Keywords: forensic psychology, history, sources

Poděkování:

Chtěla bych poděkovat všem recenzentům za jejich přínosné a cenné poznámky.

Př́íspěvek byl vytvořen $\mathrm{v}$ rámci institucionální podpory Vysoké školy finanční a správní a projektu č. 7427/2018/06.

Došlo: 16. 10. 2018

Schváleno: 12. 4. 2019 


\section{Úvod}

Psychologie má v českých zemích zajímavou historii, která je shrnuta $\mathrm{v}$ několika knihách (Hoskovec, \& Hoskovcová, 2000; Plháková, 2005; Horáková Hoskovcová, Hoskovec, \& Heller, 2016). Samotná historie forenzní psychologie je rovněž zpracována v různých publikacích, kdy obvykle jde o úvodní kapitoly v knihách zaměřených na forenzní psychologii. Proč se tedy $\mathrm{k}$ historii forenzní psychologie znovu vracet? Proč se zaobírat stále stejnými údaji, které lze nalézt v již publikovaných textech? Cílem této studie není znovu opakovat již jinde publikované informace, ale nahlédnout, jak je historie forenzní psychologie do začátku druhé světové války prezentována $\mathrm{v}$ české a slovenské psychologické literatuře. Informace jsou poté doplněny dohledáním primárních zdrojů, což bylo možné díky digitalizaci původních autorských děl. Následně je pak upozorněno na nesrovnalosti vzniklé z přenosu mezi jednotlivými zdroji.

\section{Analyzované zdroje}

V tomto textu jsem se zaměřila na kapitoly shrnující historii forenzní psychologie v šestnácti publikacích vydaných po roce 1990 (viz seznam na konci textu).

U knih, které mají více vydání, jsem se soustředila na první a poslední vydání, jako např́iklad Pavlovského „Soudní psychologie a psychiatrie“, kdy první vydání vyšlo v roce 2001 a poslední čtvrté vydání v roce 2012. Publikace byly vybrány dle následujících kritérií: učebnice forenzní psychologie a články zabývající se historií forenzní psychologie.

V rámci analýzy jsem se zaměřila na následující témata:

Ustanovení počátku forenzní psychologie v uvedených pramenech (kapitola 1)

Chronologie děl od osmnáctého století do začátku druhé světové války (rok 1939) zmíněných v uvedených pramenech (kapitola 2)

Během práce na textu vzniklo i poslední téma, které se týkalo nalezených nesrovnalostí v údajích (kapitola 3).

\section{Chronologie vývoje forenzní psychologie}

\section{Ustanovení počátku forenzní psychologie v uvedených pramenech}

Různí autoři zmiňují různá díla vydaná od dob antiky až po renesanci jako počátek oboru psychologie. Ve forenzně-psychologické literatuře je třeba zdůraznit, že zde se uvádění počátku psychologie liší podle zaměření autorů, to jest, zda se soustředí spíše na vývoj studia psychických poruch, zodpovědnosti za trestný čin či jeho právní počátky. Při analýze jsem se řídila názvy publikací a sledovala jsem, kdy se v názvu objeví slovo "psychologie“ ve spojení s jinými výrazy, jež se týkají oblasti práva. Tento př́stup je založen na definici forenzní psychologie podle Heretika (2010), který konstatuje, že: „...forenzní psychologie se věnuje psychice jednotlivých účastníků právního procesu, psychickými a sociálně-psychologickými 
zvláštnostmi jednotlivých etap jeho realizace (psychologie, vyšetřování, soudního procesu, výkonu trestu) i psychologickým problémům jednotlivých právních odvětví..." (str. 25).

$\mathrm{Na}$ základě tohoto př́stupu lze vymezit počátek forenzní psychologie publikací Karla (také Carl) von Eckartshausena (1752-1803 ${ }^{1}$ ),Nutnost psychologického posuzování a poznání zločinců“ $2{ }^{3}$ z roku 1791 a Johanna C. G. Schaumanna (1768-1821) a jeho studie „Ideje kriminální psychologie“ z roku 1792 (Netík, \& Netíková, 1994; Netík a kol., 1997; Čírtková, 2013). Právě na základě těchto dvou publikací uvádí Straus a kol. (2005) rok 1792 jako počátek forenzní disciplíny a Gustáv Dianiška (2011) zmiňuje, že „,..obsah kriminológie postupne naplňovali aj iné vedné disciplíny, napr. kriminálna psychológia (od roku 1792)..." (str.15). Z tohoto pohledu by tedy bylo možné tvrdit, že počátek forenzní psychologie lze datovat do období 1791-1792.

Dalšími prameny, u nichž lze zaznamenat počátek forenzní psychologie, jsou publikace napsané samotnými psychology. Zde bychom mohli umístit na přední místo Alberta von Schrenck-Notzinga (1862-1929), který je v Guinessově knize rekordů zaznamenán jako první forenzní psycholog, a to na základě svědectví u soudu v roce 1896, či Williama Sterna (18711938) a jeho práci „Studium výpovědi“ v časopise „Př́́spěvky k psychologii výpovědi“ (Beiträge zur Psychologie der Aussage) ${ }^{4}$ z roku 1903 (Heretik, 1992, 2010; Matoušková, 2013; Čŕrtková, \& Červinka, 1994; Čírtková, 2013). Na základě tohoto přistupu by bylo možné umístit počátek forenzní psychologie na přelom 19. a 20. století.

\section{Chronologie děl od 18. století do začátku druhé světové války (rok 1939) $v$ uvedených pramenech}

V rámci vývoje forenzní psychologie jsou nejčastěji uváděny tyto historické etapy (Čírtková, Červinka, 1994; Sochůrek, 2002; Matoušková, 2013; Čírtková, 2013):

Nastoleni forenzně psychologické problematiky v 2. polovině. 18. století (část 2.1)

Vývoj forenzně psychologického zkoumání v 19. století (část 2.2)

Vznik forenzní psychologie jako experimentální disciplíny na počátku 20. století

Rozvoj forenzni psychologie ve 20. století

Poslední dvě období (Vznik forenzní psychologie jako experimentální disciplíny na počátku dvacátého století a Rozvoj forenzní psychologie ve dvacátém století) již nejsou oddělena chronologicky, ale spíše se prolínají.

\footnotetext{
${ }^{1}$ U všech osobností jsou uvedeny údaje týkající se data narození a úmrtí.

${ }^{2}$ Někteří autoři uvádějí původní názvy děl, jiní používají český překlad. Pokud český překlad chybí, dovoluji si navrhnout vlastní.

${ }^{3}$ Eckarthausenovo dílo je často datováno 1792, ačkoli jeho kniha vyšla v roce 1791. Správná citace byla ověřena u Schneidera (2014).

${ }^{4}$ Sternovy publikace jsou více analyzovány v kapitole 3 Nesrovnalosti v údajích.
} 
V tomto textu tedy přecházím na dělení 20 . století na tyto etapy:

Od počátku století do prvni světové války (1900-1914) - část 2.3

Období mezi světovými válkami (1918-1939) - část 2.4

Zde zmiňovaná díla a jejich autoři pochází z šestnácti pojednávaných publikací ${ }^{5}$. Pro celistvost jsem seřadila autory každého období chronologicky a doplnila údaje o plná jména autorů, data narození a úmrtí, plné názvy prací (v textu jsou české názvy prací, původní názvy jsou v seznamu literatury) a úplnou citaci daného díla. Často jsem doplnila informace dohledáním primárních zdrojů a pokud to nebylo možné, tak dohledáním sekundárních pramenů, vydaných časově co nejblíže primárnímu zdroji, přičemž seznam primárních a sekundárních zdrojů je uveden na konci textu. Citované prameny v textu jsou publikace, v nichž jsem dohledávala další informace, které v českých a slovenských publikacích nebyly uvedeny.

\subsection{Nastolení forenzně psychologické problematiky v 2. polovině 18. století}

Časová posloupnost tohoto období je dle této rešerše následující: Cesare Beccaria (17381794) a jeho dílo „O zločinech a trestech“ (1764) ${ }^{6}$, trestní zákoník „Constitutio criminalis Theresiana“ (1768), který specifikuje, které chorobné stavy vedou k vyvinění nebo zmírnění trestu, dále dílo Carla (Karl) von Eckartshausena (1752-1803) „Nutnost psychologického posuzování a poznání zločincư“ $(1791)^{7}$ a kniha Johanna C. G. Schaumanna (1768-1821) s názvem „Ideje kriminální psychologie“8 ${ }^{\text {z }}$ roku 1792. Důležitý je také rok 1793, kdy se Phillippe Pinel (1745-1826) stal vedoucím nemocnice Bicêtre na jihu Paříže, kde začal pracovat $\mathrm{s}$ duševně nemocnými na základě nenásilných (psychologických) postupů. Pinel své poznatky zpracoval v roce 1794 do eseje „Vzpomínky na šílenstvi“‘9, jež je nyní považována za základní text moderní psychiatrie (Weiner, 1992). Konec této éry uzavírá publikace Johanna G. Müncha (1774-1837) „O vlivu kriminální psychologie na systém trestního práva“10 z roku 1799.

Celé období obsahuje publikace zejména z oblasti práva a psychiatrie (s malými psychologickými ,vlaštovkami““). V této době byly tedy budovány právní a psychologickopsychiatrické poznatky, které podle Heretika (1992) vytvořily předpoklady pro vznik forenzní psychologie. Zároveň je to období, do něhož zařazujeme počátek oboru forenzní psychologie jako takové. Lze tedy shrnout, že tato léta jsou obdobím vytváření předpokladů pro rozvoj forenzní psychologie.

\footnotetext{
${ }^{5}$ Zde se dovoluji podotknout, že rozhodně nepovažuji tento výčet autorů a děl za kompletní. Více na toto téma pojednávám $\mathrm{v}$ závěru článku.

${ }^{6}$ Český překlad vyšel v Praze v roce 1893. Plná verze českého překladu je zde. Italská původní verze je zde.

${ }^{7}$ Plná verze je zde.

${ }^{8}$ Plná verze je zde.

${ }^{9}$ Překlad autorky. Francouzský originál eseje se nepodařilo dohledat.

${ }^{10}$ Překlad autorky. Plná verze je zde.
} 


\subsection{Vývoj forenzně psychologického zkoumání v devatenáctém století}

Mezi významná jména devatenáctého století patří Johann C. Hoffbauer (1766-1827), který v roce 1808 vydal dílo „Psychologie a její použití v soudnictví“11. V roce 1810 Anton Parst $^{12}$ vydává své pojednání o sugesci a rizicích během procesu vyšetřování (Ueber Suggestionen und ihre Gefährlichkeit im Criminal-Processe: ein Versuch) (Mittermaier, $1827^{13}$; Walther, $1854^{14}$ ). O osmnáct let později, v roce 1828 , byl vydán text A. R. (Paul Johann Anselm Ritter) von Feuerbacha (1775-1833) s názvem „Zvláštní a tajemné př́ípady ve světle soudních spisư“"15. Následně Adolphe Quételet (1796-1874) v roce 1831 publikuje své poznatky „K vývoji sklonu ke kriminalitě“"16 (McLaughlin, \& Muncie, 2003; Beirne, 1987).

Johannes B. Friedreich (1796-1862) v roce 1835 zveřejnil „Základy soudní psychologie“17 18 a v roce 1836 Leopold von Thun-Hohenstein (1811-1888) vydává publikaci o „Nezbytnosti mravní reformy vězeňství“ (Fořtová, \& Olšáková, 2012). První polovinu devatenáctého století můžeme uzavřít prací Ludwiga Hugo Franz von Jagemanna (1803/18041889) „Prostředky k potlačení zneužívání vyšetřovateli“19 vydanou v roce 1839 (Feuerbach, $\left.1840^{20}\right)$.

Toto období lze obecně charakterizovat rozvojem prací, které se věnují psychologickým tématům jako je sugesce a výslech. Zároveň se objevují díla ryze obecná jako „Základy soudní psychologie“ a „Psychologie a její použití v soudnictví“. Celkově bychom tak toto období mohli popsat jako zakotvení oboru forenzní psychologie.

Druhá polovina devatenáctého století je podle Netíka a kol. (1997) definována jako kriminalistická. Toto období začíná vydáním knihy „Základy kriminální psychologie“²1 (1872) od Richarda von Krafft-Ebinga (1840-1902), dále publikací Cesare Lombrosa (1835-1909) „Člověk zločinný، “22 z roku 1876 a založením první psychologické laboratoře v Lipsku Wilhelmem Wundtem (1832-1920) v roce 1879 (Vobořil, Kvetoň, \& Jelínek, 2009).

11 Plná verze je zde.

12 Rok narození a úmrtí jsem nebyla schopna dohledat.

${ }^{13}$ Plná verze zde.

${ }^{14}$ Plný text zde.

15 Plný text je zde.

16 Překlad autorky. Plná verze je v McLaughlin, Muncie (2013).

17 Tato publikace je dalším př́kladem nejednotnosti překladů názvů a také přenosu chyb ve jménech autorů. Viz více v kapitole 3 Nesrovnalosti v údajích.

${ }_{18}$ Český název je přejat od Heretika (2010). Plná verze je zde.

19 Přeloženo autorkou.

${ }^{20}$ Citace nalezena zde.

${ }^{21}$ Tato publikace je př́kladem, kdy je častěji citováno druhé vydání než první. Viz více v kapitole 3 Nesrovnalosti v údajích. Plný text je zde.

22 Č́rtková a Červinka (1994) uvádějí rok vydání 1890. Název je přejat dle Sochůrka (2002) „Člověk zločinný ve vztahu k antropologii, právní vědě a psychiatrii“. Citace ověřena v Burgalassi, 1996. 
K významným počinům patří i publikace Raffaela Garofala (1851-1934) s názvem „Kriteria pozitivního trestu“23, která vyšla v roce 1880.

Při výčtu dalších autorů nelze opomenout Tomáše G. Masaryka (1850-1937) a jeho dílo z roku 1881, které nazval „Sebevražda jako sociální jev současnosti“ ${ }^{\text {“24 }}$. V roce 1883 pak vydává Emil Kraepelin (1856-1926) svou hlavní práci „Kompendium psychiatrie: pro studenty a lékaře“ $^{\text {25 }}$. O rok později v roce 1884 vychází „Psychologie zločince“ ${ }^{\text {26 }}$ od Augusta Krausse, a také „Kriminální sociologie“ 27 od Enrica Ferri (1856-1929). Raffaele Garofalo (1851-1934) v roce 1885 publikuje text s názvem „Kriminologie: studie o trestné činnosti, jejích příčinách a způsobech represe“28. V následujícím roce potom vydává Gabriel Tarde (1843-1904) „Srovnání kriminality ${ }^{\text {“29. }}$.

Poslední desetiletí devatenáctého století bylo velice zajímavé na publikace, a to nejen v oboru forenzní psychologie. Hans Gross (1847-1915) publikuje „Rukověti pro vyšetřující soudce“ $v$ roce $1893^{30}$. Sám Gross poznamenává, že ,„,... ze všech znalostí, které jsou trestnímu soudci potřebné, kromě vědomostí z práva, jsou nejdůležitější poznatky z psychologie, nebot' ho učí znát člověka...“ (Hoskovec, \& Hoskovcová, 2000, str. 164). James McKeen Cattell (1860-1944) ve stejném roce poukazuje na nespolehlivost svědecké výpovědi (1895) ${ }^{31}$ (Weiner, Hess, 2006) a Émile Durkheim (1858-1917) publikuje knihu „Dělba práce ve společnosti“32, v níž poprvé představuje termín anomie. Zaznamenáníhodné je, že v roce 1896 Albert von Schrenck-Notzing (1862-1929) ${ }^{33}$ svědčil u soudu v př́ípadu vraždy tř́ žen a mimo jiné upozorňoval na to, jak senzacechtivé zpravodajství v novinách ovlivňuje pamět' svědků (Gudjonsson, \& Haward, 2016; Weiner, \& Hess, 2006). Dále v roce 1897 publikuje Émile Durkheim (1858-1917) své dílo „Sebevražda“334.

${ }^{23}$ Překlad autorky. Plný text čtvrtého vydání z roku 1896 je zde.

${ }^{24}$ České vydání z roku 1904 je zde. Německé vydání z roku 1881 je zde. Překlad je převzat z díla Látalové a kol., 2015.

${ }^{25}$ Tato publikace je dobrým př́kladem, kdy se v kapitolách o historii forenzní psychologie objevuje jméno autora, ale bez udání díla či data. Zde jsem tedy vybrala dílo nejvýznamnější. Plná verze je zde. Anglickou zkrácenou verzi lze nalézt zde.

${ }^{26}$ Plný text je zde.

${ }^{27}$ Překlad autorky. Italské čtvrté vydání z roku 1900 je zde. Anglická verze z roku 1917 je zde.

${ }^{28}$ Plný text zde.

${ }^{29}$ Plný text zde.

${ }^{30}$ Citace ověřena v díle Liebranda a Schösslera (2004).

31 V literatuře je nejčastěji zmiňován rok 1893, kdy byly experimenty provedeny. Samotná publikace vyšla $v$ roce 1895 . Plný text je zde.

32 V kapitolách není uvedeno přesné dílo. Umist’uji Durkheima zde na základě tohoto, pro forenzní psychologii, nejdůležitějš́ího díla. Plný text je zde.

33 Pro zajímavost - Albert von Schrenck-Notzing je v Guinessově knize rekordů zaznamenán jako první forenzní psycholog. Své zkušenosti popsal v publikaci z roku 1897.

${ }^{34}$ Plný text ve francouzském jazyce je zde. 
V roce 1898 vydává Hans Gross (1847-1915) svou stěžejní knihu „Kriminální psychologie“35 [Kriminalpsychologie], díky níž stojí u ,zrodu forenzní psychologie jako experimentální a odborně provozované disciplíny“ (Č́rtková, \& Červinka, 1994, str. 195). Gross je také často začleňován do vývoje české forenzní psychologie, protože v letech 19021904 přednášel v Praze (Grassberger, 1956). Století pak uzavírá Cesare Lombroso se svou publikací z roku 1899 „Trestný čin: příčiny a nápravy“3636 (Knepper, \& Ystehede, 2013).

Obecně lze říci, že forenzní psychologie zažívá ve druhé polovině osmnáctého století značný rozvoj, a to díky publikacím, které se zabývají nejen jí, ale také kriminologií a kriminalistikou. Toto období tedy můžeme definovat jako propojení forenzní psychologie s př́ibuznými obory.

\subsection{Obdobi od počátku století do první světové války - 1900-1914}

Období od počátku století do první světové války označuje Čírtková a Červinka (1994) a Sochůrek (2002) za období výpovědi. Autoři Netík a kol. (1997) je považují za etapu soudní na základě prací J. M. Cattella (1860-1944) ${ }^{37}$ a H. Münsterberga (1863-1916). Z mého pohledu tato perioda začíná prací Alfreda Bineta (1857-1911) nazvanou „Sugestibilita“ z roku $1900^{38}$ (Heretik, 2010). V roce 1903 začíná vycházet v Lipsku časopis „Příspěvky k psychologii výpovědi“ (Beiträge zur Psychologie der Aussage ${ }^{39}$ ), ve kterém také publikuje William Stern (1871-1938) ${ }^{40}$ svůj článek „Studium výpovědi““41. V roce 1904 Max Wertheimer (1880-1943) i Carl G. Jung (1875-1961) začínají publikovat v oblasti slovně-asociační metody týkající se detekce komplexů spojených s vinou $\mathrm{z}$ trestné činnosti. Wertheimer tuto oblast nazývá Tatbestandsdiagnostik (King, \& Wertheimer, 2005). Wertheimer publikuje v časopise „Archiv pro kriminální antropologii a kriminalistiku“ (Archiv für Kriminalanthropologie und Kriminalistik) ${ }^{42}$, zatímco Jung publikuje v Časopise pro psychologii a neurologii ${ }^{43}$ (Journal für Psychologie und Neurologie). Zajímavostí je pak kauza, v níž se řešilo, kdo v této oblasti začal publikovat jako první (Wertheimer a kol., 1992 ${ }^{44}$; King, \& Wertheimer, 2005).

Heretik (2010) jako jediný zmiňuje vývoj v Rusku, zejména zastoupený Vladimirem M. Bechtěrevem (1857-1927), který byl od roku 1885 až do roku 1893 ředitelem psychiatrické

\footnotetext{
${ }^{35}$ V české literatuře se velice často uvádí rok 1905, to je ovšem rok druhého vydání. První vydání vyšlo v roce 1898 (Straus a kol., 2005).

${ }^{36}$ Přeloženo autorkou. Anglická verze z roku 1911 zde.

${ }^{37}$ Dle chronologie však Cattell patří do období předchozího.

${ }^{38}$ Plný text zde.

${ }^{39}$ Plný text zde.

${ }^{40}$ Č́rtková (2013) zmiňuje Sterna také v roli soudního znalce.

${ }^{41}$ Plný text zde.

${ }^{42}$ Plný text zde.

${ }^{43}$ Plný text anglické verze zde (Jung, C.G., 2015).

${ }^{44}$ Plný text zde.
} 
léčebny ${ }^{45}$ a založil časopis Věstník psychologie, kriminální antropologie a hypnózy (Vestnik psikhologii, kriminal'noi antropologii i gipnoza), který vycházel od roku 1904 do roku 1919. V roce 1912 byl jeho název změněn na „Věstník psychologie, kriminální antropologie a paidologie“"46 (Byford, 2016).

V roce 1905 publikuje Édouard Claparède (1873-1940) článek „Soudní psychologie“477. Téhož roku v českých zemích vydává František Krejčí (1858-1934) příspěvek „Asociační metoda kriminalistická“, který shrnuje výzkumy Wertheimera a Kleina a popisuje replikaci jejich výzkumů na pražské univerzitě, v roce 1906 vydává text s názvem „K psychologii výpovědi“ “ ${ }^{48}$. V témže roce je $\mathrm{v}$ Berlíně založen Institut pro aplikovanou psychologii a psychologický výzkum (Institut für Angewandte Psychologie und psychologische Sammelforschung ${ }^{49}$. Tento institut byl významný, protože se mimo jiné podílel na vývoji personalistiky (Schmitt, 2013), což se také vztahovalo k výběru uchazečů do řad policie. Paul Eugen Bleuler (1857-1939) ve své přednášce v Berlíně 24. dubna 1908 poprvé představuje termín „schizofrenie“ (Ashok a kol., 2012). Hugo Münsterberg (1863-1916), zakladatel aplikované psychologie, pak v roce 1908 vydává knihu o důkazní hodnotě svědeckých

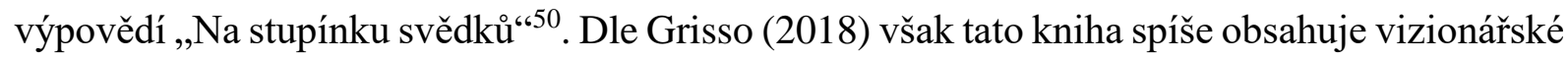
hypotézy týkající se aplikace psychologie v oblasti práva.

Prvním počinem ve Spojených státech amerických, který je často zmiňován, je založení kliniky Juvenile Psychopathic Institute v Chicagu, a to Grace M. Fernaldovou (1879-1950) a Williamem Healym v roce 1909 (Wicks-Nelson, Israel, 2013). Zajímavé je, že ač psychologická literatura zmiňuje podíl Fernaldové na založení institutu (Bartol, \& Bartol, 1999), v jiných textech Fernaldová figuruje až v rámci publikace týkající se testování (Wagner, 198151; Healy, \& Fernald, 1911), nebo vůbec není uváděna (Gardner, 1964).

V Evropě v roce 1910 Hans Reichel ${ }^{52}$ vydává knihu „O forenzní psychologii““53. Hans Gross o dva roky později zakládá Císařský kriminologický institut na univerzitě v Grazu (Chisum, \& Turvey, 2011). V roce 1913 vydává Karl Marbe (1869-1953) „Základy forenzní psychologie“ “54 a další rok publikuje Henry H. Goddard (1866-1957) práci „Chabá mysl: př́íčiny

${ }^{45}$ Více o vývoji forenzní psychologie v Rusku lze nalézt v díle Shaboltase (2017).

${ }^{46}$ Heretik (2010) zmiňuje publikaci „Objektivní psychologické metody v aplikacii na výzkum zločinnosti“" $\mathrm{z}$ roku 1912, kterou se mi nepodařilo vyhledat.

${ }^{47}$ Tato práce je více pojednána v kapitole 3 Nesrovnalosti v údajích. Plný text je zde.

${ }^{48}$ Časopis Česká mysl je zde.

${ }^{49}$ Č́rtková (2013) uvádí německý název institutu.

${ }^{50}$ Přeloženo autorkou. Anglická verze je zde.

${ }^{51}$ Plný text zde.

${ }^{52}$ Nepodařilo se mi dohledat datum narození a úmrtí.

${ }^{53}$ Citace ověřena v díle Wolframa, 2018.

${ }^{54}$ Citace ověřena v díle Wolframa, 2018. 
a následky“55. Toto období uzavírá zajímavá publikace „Výběr policistư“56 od Lewise M. Termana (1877-1956), která vyšla v roce 1916 ve Spojených státech (Holmes, 1942).

Léta od počátku 19. století do první světové války byla velice plodná, co se týče různých publikací v oblasti forenzní psychologie. Z mého pohledu definování tohoto časového úseku jako období zaměřeného na výpověd', jak navrhují již zmínění autoři, je značně limitující. Spíše by se tyto roky daly nazvat obdobím rozmachu a rozvoje forenzní psychologie a jejích jednotlivých disciplín, jako je soudní psychologie a policejní psychologie.

\subsection{Období mezi světovými válkami - 1918-1939}

Na počátku tohoto časového úseku stojí práce Louise L. Thurstonea (1887-1955) z roku 1922 „Inteligence policistư“‘57 a studie Augusta Aichhorna (1878-1949) o mládeži z roku $1925^{58,59}$. Důležitým aspektem meziválečného období je vývoj detektoru lži. V roce 1921 John A. Larson (1892-1965) modifikoval př́stroj nazvaný sfygmomanometr tak, aby mohl graficky zobrazit činnost srdce, a aplikoval ho pro policejní vyšetřování. William Moulton Marston (1893-1947) vynalezl test systolického krevního tlaku, který se stal součástí polygrafu právě sestrojeného Larsonem. V roce 1935 Leonarde Keeler (1903-1949) začal měnit a zlepšovat Larsonův př́istroj, později byl tedy nazván Keelerův polygraf (Segrave, 2004).

Perioda mezi oběma válkami již také obsahuje více prací publikovaných v tehdejším Československu. Rozvoj forenzní psychologie a kriminologie u nás byl ovlivněn zejména založením Kriminologického ústavu na Právnické fakultě Univerzity Karlovy v roce 1926 a také založením Kriminologického institutu Německé univerzity v Praze (Zoubková a kol., 2018). Zde také působila Jarmila Veselá (1899-1972), která v roce 1928 vydává článek „Obviněný jako předmět trestního řízení a psychologické metody zjištování skutkových okolností“ (Fenyk, 2009). Důležitým dílem je kniha Josefa Šejnohy (1901-? ${ }^{60}$ ) „Kriminální psychologie“" vydaná roku 1930, která je první publikací o forenzní psychologii napsaná $\mathrm{v}$ češtině.

Forenzní psychologie se také objevuje v publikacích prríbuzných oborů. Josef Lebeda v roce 1931 publikuje „Učebnici kriminalistiky“ a Vítězslav Čelanský v roce 1932 „Vyšetřovací metody bezpečnostní služby“ (Straus a kol., 2005). Toto období uzavírá práce Františka Kafky „O psychobiologickém výzkumu v kriminologii“ (1933) (Solnař, 1933) a dílo Franze Alexandera (1891-1964) a Williama Healyho z roku 1935 "Kořeny zločinu“61.

\footnotetext{
${ }^{55}$ Přeloženo autorkou. Plný text zde. .

${ }^{56}$ Přeloženo autorkou.

${ }^{57}$ Přeloženo autorkou. Plný text zde. .

${ }^{58}$ Plný text zde.

${ }^{59}$ Německý název je možno přeložit jako „Zanedbané mládi“, ovšem více známější anglický název „Wayward youth“ lze přeložit jako „Mladí, kteří sešli z cesty“.

${ }^{60}$ Nepodařilo se mi dohledat datum úmrtí.

${ }^{61}$ Přeloženo autorkou. Citace ověřena v Cullen, Wilcox, 2010.
} 
Č́rtková a Červinka (1994) a Sochůrek (2002) označují meziválečná léta za období svědka. Historicky je toto období poznamenáno devastací Evropy po první světové válce. Německo a Rakousko-Uhersko, kdysi centra rozvoje forenzní psychologie, jsou v ruinách. Vývoj pokračuje ve Spojených státech amerických. Zároveň se v tomto období objevují publikace již ryze české. Celkově by se tato doba dala charakterizovat jako období hledání nových směrů. Toto pojetí také navazuje na pojmenování období od roku 1890 do roku 1930 v americké literatuře jako období zrození soudní psychologie (Grisso, 2018).

Na základě tohoto náhledu do chronologie forenzní psychologie také vzniklo poslední téma této studie:

\section{Nesrovnalosti v údajích a doplnění informací s použitím internetových zdrojů}

V rámci práce na tomto příspěvku jsem ověřovala veškeré informace $\mathrm{z}$ analyzovaných pramenů přímo u primárních či sekundárních zdrojů vydaných časově co nejblíže původnímu zdroji. Intenzivně jsem dohledávala doplňující informace s použitím různých internetových pramenů, zejména originály autorských děl pro ověřní či pro doplnění citace, což je nyní díky digitalizaci knihovních fondů možné. Při hledání jsem zachytila různé nesrovnalosti, které se objevují v kapitolách pojednávajících o historii forenzní psychologie, a jež vznikly v důsledku přenosu ze starších publikací v dobách, kdy možnost ověřit si informace u primárních zdrojů byla složitá či prakticky nemožná.

Problémem bylo např́klad dohledání roku publikace díla, kdy u různých publikacích byla uváděna odlišná data. U autora A. R. von Feuerbacha je pak udáván rok publikace 1829, ale správně je 1828. U A. Aichhorna je uváděn rok vydání 1935, což je ale rok anglického vydání, zatímco původní publikace vyšla v roce 1925. U J. B. Friedreicha je uváděno datum vydání 1832 místo 1835, u K. Marbeho je uváděn rok 1912 místo 1913.

Navazujícím problémem je uvádění různých překladů původního názvu. To je problém textu Johanna C. G. Schaumanna (1768-1821) a jeho „Ideen zu einer Kriminalpsychologie“ z roku 1792. Netík a Netíková (1994) a Netík a kol. (1997) mluví o „Úvodu do kriminální psychologie“, Záhorská (2007) cituje „Ideje kriminální psychologie“ a Straus a kol. (2005) mluví o „Myšlenkách kriminální psychologie“, přičemž ve všech př́ipadech se jedná o tentýž text.

U publikace „Systematisches Handbuch der gerichtlichen Psychologie: für Medicinalbeamte, Richter und Vertheidiger“ Johannese B. Friedreicha z roku 1835 byl podobný problém. Heretik (2010) uvádí název „Základy soudní psychologie“, Sochůrek (2002) a Čírtková (2013) oproti tomu citují „Rukovět' soudní psychologie“.

Ovšem některé publikace vyžadovaly téměř detektivní práci. Např́íklad u vyhledání díla E. Claparèdeho: Heretik (2010) o něm píše obecně jako o soudní psychologii z roku 1912, Sochůrek (2002) uvádí rok 1906 a přednášky konané v Ženevě, Čírtková (2013) sice zmiňuje původní název ve francouzštině, ale udává rok vydání 1906 a také píše o knize. Přitom se ve skutečnosti jednalo o článek z roku 1905. 
Práce Williama Sterna (1871-1938) byla dalším oříškem. Často uváděný název publikace je totiž ve skutečnosti název časopisu, který Stern vydával a v němž publikoval své práce.

\section{Závěr}

Samotná práce na tomto textu mne dovedla k reflexi, že často bereme historické publikace jako body v čase. Avšak o publikacích bychom měli přemýšlet spíše jako o časovém kontinuu. Autor o svém díle hovořil s ostatními kolegy, byl ovlivňován svými předchůdci i svými zkušenostmi, např. výzkum J. M. Cattella byl průvodním momentem pro další výzkum týkající se psychologie výpovědi ve Spojených státech a A. Binet jeho výzkum replikoval ve Francii (Weiner, \& Otto, 2014). Autor také o své práci přednášel a vychovával své následovníky, např. E. Kraepelin, J. M. Cattell či H. Münsterberg studovali ve Wundtově institutu (Vobořil, et al, 2009). Po vydání autorovo dílo dále ovlivňovalo jeho následovníky.

Druhá reflexe se týká blízké propojenosti forenzní psychologie s obory jako je kriminologie, psychiatrie, sociologie, lékařství, a pokud se věnujeme dějinám forenzní psychologie, tak také historiografie. Zde uvedená díla jsou pouze ta, která se objevují v českých a slovenských knihách zabývající se forenzní psychologií. Je tedy otázkou, jaká díla nalezneme, pokud se ponoříme do historie těchto oborů, protože pak se studium historie forenzní psychologie stane ještě více zajímavé. Dalším krokem je tedy bádání po dílech, o kterých se v novodobé literatuře již nepíše, která se do současného povědomí již nedostala a zejména po dílech, jež jsou známá v oborech jako je lékařství či historie, a přitom se k forenzní psychologii vztahují. Doufám tedy, že tento text inspiruje mnohé k nahlédnutí do této fascinující oblasti historie forenzní psychologie.

\section{Analyzované publikace}

Čírtková, L. (2013). Forenzní psychologie. Plzeň: Aleš Čeněk.

Čírtková, L., \& Červinka, F. (1994). Forenzní psychologie. Praha: Support.

Heretik, A. (1992). Úvod do forenznej psychológie pre posluchačov právnických fakúlt. Právnická fakulta Univerzity Komenského v Bratislave.

Heretik, A. (2010). Forenzná psychológia pre psychológov, právnikov, lekárov a iné pomáhajúce profesie. Bratislava: Eurokodex.

Houbová, D. a kol. (2008). Psychologie pro právníky. Plzeň: Aleš Čeněk.

Netík, K., \& Netíková, D. (1994). Vybrané kapitoly z forenzní psychologie pro právníky. Praha: Karolinum.

Netík, K., Netíková, D., \& Hájek, S. (1997). Psychologie v právu. Praha: C.H. Beck.

Matoušková, I. (2013). Aplikovaná forenzní psychologie. Praha: Grada.

Pavlovský, P. a kol. (2012). Soudní psychiatrie a psychologie. Praha: Grada.

Pavlovský, P. a kol. (2001). Soudní psychiatrie a psychologie. Praha: Grada. 
Sochůrek, J. (2002). Nástin vybraných problémů forenzní psychologie. Liberec: Technická univerzita.

Straus, J., Vavera F., \& Novák, Z. (2005). Dějiny forenzní psychologie v českých zemích. Policista, 5.

Výrost, J., \& Slaměník, I. (eds.) (1998). Aplikovaná sociální psychologie I.: Člověk a sociální instituce. Kapitola: Člověk a zákon. Praha: Portál.

Záhorská, J. (2007). Psychologická intervence při vyšetřování trestných činů. Praha: Portál.

\section{Primární zdroje (chronologické řazení)}

Beccaria, C. (1764). Dei delitti e delle pene.

von Eckartshausen, C. (1791). Über die Notwendigkeit physiologischer Kenntnisse bei der Beurteilung der Verbrechen. München.

Schaumann, J. (1792). Ideen zu einer Kriminalpsychologie. Halle: Gebauer.

Münch, J.G. (1799). Über den Einfluß der Criminal-Psychologie auf ein System des CriminalRechts, auf menschlichere Gesetze und Cultur der Verbrecher. Nürnberg: Stein.

Hoffbauer, J. C. (1808). Die Psychologie in ihren Hauptanwendungen auf die Rechtspflege nach den allgemeinen Gesichtspunkten der Gesetzgebung oder sogenannte gerichtliech Arzneywissenschaft nach ihrem psychologischen Theile. Halle: Schimmelpfennig.

von Feuerbach, A. R. (1828). Aktenmäßige Darstellung merkwürdiger Verbrechen. Giessen: Heyer.

Friedreich, J. B. (1835). Systematisches Handbuch der gerichtlichen Psychologie: für Medicinalbeamte, Richter und Vertheidiger. Leipzig: Wigand.

von Krafft-Ebbing, R. (1872). Grundzüge der Kriminalpsychologie auf Grundlage der deutschen und österreichischen Gesetzgebung.

Lombroso, C. (1876). L'Uomo Delinquente. Milan.

Masaryk, T. G. (1881). Der Selbstmord als soziale Massenerscheinung der Gegenwart.Wien: Verlag von Carl Konegen.

Kraepelin, E. (1883). Compendium der Psychiatrie: Zum Gebrauche für Studirende und Aerzte. Leipzig: Abraham Abel.

Krauss, A. (1884). Die Psychologie des Verbrechens: Ein Beitrag zur Erfahrungsseelenkunde. H. Lapp.

Ferri, E. (1884). Sociologia criminale. Torino.

Garofalo, R. (1885). Criminologia: Studio sul Delitto, Sulle sue Cause e sui Mezzi di Repressione. Torino: Fratelli Bocca.

Tarde, G. (1886). La criminalité comparée. Paris.

Beccaria, C. (1893). O zločinech a trestech. Přeložil a poznámkami opatřil Josef Sládeček. V Praze: V kommissi knihkupectví: Bursík a Kohout. 
Durkheim, E. (1893). De la division du travail social. Paris: Les Presses universitaires de France, 1967, huitième édition, 416 pp. Collection: Bibliothèque de philosophie contemporaine.

Durkheim, E. (1897). Le suicide: Étude de sociologie. Paris: Les Presses universitaires de France, 2e édition, 1967, 462 pages. Collection: Bibliothèque de philosophie contemporaine.

Durkheim, E. (2004). Společenská dělba práce. Centrum pro studium demokracie a kultury.

Cattell, J. M. (1895). Measurements of the accuracy of recollection. Science, 2, 761-766.

Masaryk, T. G. (1904). Sebevražda hromadným jevem společenským moderní osvěty. Praha: Jan Laichter.

Gross, H. (1898). Kriminalpsychologie. Graz: Leuschner \& Lubensky.

Lombroso, C. (1899). Le crime; causes et remédes. Paris.

Binet, A. (1900). La Suggestibilité. Paris: Schleicher.

Stern, W. (1903). Aussagestudium. Beiträge zur Psychologie der Aussage, 1, 46-78.

Wertheimer, M., \& Klein, J. (1904). Psychologische Tatbestandsdiagnostik. Archiv für Kriminalanthropologie und Kriminalistik, 15, 72-113.

Claparède, E. (1905). La psychologie judiciaire. L'année psychologique, 12(1), 275-302.

Krejčí, F. (1905). Asociační metoda kriminalistická. Česká mysl, 6(2), 158-159.

Krejčí, F. (1906). Ke psychologii výpovědi. Česká mysl, 7(2), 159.

Münsterberg, H. (1908). On the winess stand: Essays on psychology and crime. New York, NY: Doubleday, Page.

Reichel, H. (1910). Über forensische Psychologie. München.

Goddard, H.H. (1914). Feeblemindedness, its causes and consequencies. New York: Macmillan.

Thurstone, L. L. (1922). The Intelligence of Policemen. Journal of Personnel Research, 1, 6474.

Aichhorn, A. (1925). Verwahrloste Jugend: Die Psychoanalyse in d. Fürsorgeerziehung; 10 Vorträge zur ersten Einführung. Wien: Internationaler Psychoanalytischer Verlag, 1925, (Engl. Wayward Youth, New York: Viking Press, 1935).

Šejnoha, J. (1930). Kriminální psychologie. Praha: Československý detektiv.

Čelanský, V. (1932). Vyšetřovací metody bezpečnostní služby. Zemědělské knihkupectví A. Neubert.

\section{Sekundární zdroje}

Alexander, F., Healy, W. (1935). Roots of crime. New York: Knopf.

Ashok, A., Baugh, J., \& Yeragani, V. (2012). Paul Eugen Bleuler and the origin of the term schizophrenia. Indian Journal of Psychiatry, 54(1), 95-96. 
Bartol, C. R., \& Bartol, A. M. (1999). History of forensic psychology. In I. B. Weiner, A. K. Hess (Eds.), The Handbook of Forensic Psychology. Wiley.

Beirne, P. (1987). Adolphe Quételet and the Origins of Positivist Criminology. American Journal of Sociology 92(5), 1140-1169.

Burgalassi, M. (1996). Itinerari di una scienza: La sociologia in Italia tra Otto e Novecento. Milano, Italy: FrancoAngeli.

Byford, A. (2016). V. M. Bekhterev in Russian child science, 1900s-1920s: „Objective psychology"/"reflexology" as a scientific movement. Journal of History of Behavioural Sciences, 52(2), 99-123.

Cullen, F.T., \& Wilcox, P. (2010). Encyclopedia of Criminological Theory. Vol. 2. Sage.

Fenyk, J. (2009). Jarmila Veselá. In P. Skřejpková, P. (ed.), Antologie československé právní vědy v letech 1918-1939. Praha: Linde.

Feuerbach, A. (1840). Lehrbuch des gemeinen in Deutschland gültigen peinlichen Rechts. Giessen.

Fořtová, H., \& Olšáková, D. (2012). Lev Thun-Alexis de Tocqueville: Korespondence 18351856. Praha: Oikoymenh.

Gardner, G. E. (1964). William Healy 1869-1973. American Journal of Orthopsychiatry, Mental Health and Social Justice, 34(5), 960-964.

Garofalo, R. (1880). Di un Criterio Positivo della Penalità. Napoli: Leonardo Vallardi.

Grassberger, R. (1956). Pioneers in criminology: Hans Gross (1847-1915). Journal of Criminal law, Criminology, and Police Science, 47(4), 397-405.

Grisso, T., \& Brodsky, S. L. (2018). The Roots of Modern Psychology and Law: A Narrative History. Oxford University Press.

Gross, H. (1893). Handbuch für Untersuchungsrichter als System der Kriminalistik. Neubearbeitung v. Friedrich Geerds.

Gudjonsson, G. H., \& Haward, L.R.C. (2016). Forensic Psychology: A guide to practice. London: Routledge.

Healy, W., \& Fernald, G. M. (1911). Tests for Practical Mental Classification. Monograph No. 54. Psychological Review Pub. Co., Princeton University, Princeton, N. J.

Holmes, B. (1942). Selection of Patrolmen. Journal of Criminal Law and Criminology, 32(5), 575-592.

Horáková Hoskovcová, S., Hoskovec, J., \& Heller, D. (2016). Dějiny české a slovenské psychologie. Praha: Karolinum.

Hoskovec, J., \& Hoskovcová, S. (2000). Malé dějiny české a středoevropské psychologie. Praha: Portál.

Chisum, W. J., \& Turvey, B. (2011). Crime Reconstruction. London: Academic Press.

Jung, C. G. (1907). Über die Reproduktionsstörungen beim Assoziationsexperiment. Journal für Psychologie und Neurologie, 9(4), 188-197. 
Jung, C. G. (2015). Collected Works of C. G. Jung: The First Complete English Edition of the Works of C. G. Jung. Routledge.

Kafka, F. (1933). O psychobiologickém výzkumu v kriminologii. Praha: Nakladatelství Němec a spol.

King, D. B., \& Wertheimer, M. (2005). Max Wertheimer and Gestalt theory. Transaction Publishers.

Knepper, P., \& Ystehede, P. (2016). The Cesare Lombroso Handbook. London: Routledge.

Látalová, K., Kamarádová, D., Praško, J. (2015). Suicidalita u psychických poruch. Praha: Grada.

Lebeda J. (1931). Učebnice kriminalistiky: O zločinu a jeho potírání, daktyloskopii a jiných zjištovacích metodách, soudním lékařství, všeobecné kriminální ústředně a o

vězeňství. Praha: Jan Odvárka.

Liebrand, C., Schössler, F. (2004). Textverkehr Kafka und die Tradition. Köningshausen und Neumann.

Marbe, K. (1913). Grundzüge der forensischen Psychologie. Vorlesungen. München: C.H. Beck.

McLaughlin, E., \& Muncie, J. (2013). Criminological perspectives: Essential readings. Sage.

Mittermaier, C. J. A. (1827). Das deutsche Strafverfahren. Heidelberg.

Parst, A. (1810). Über Suggestionen und ihre Gefarlichkeit im Criminal Process. Landshut, Thomann.

Plháková, A. (2005). Učebnice obecné psychologie. Praha: Academia.

Quetelet, A. (1831). Of the development of the propensity to crime.

Segrave, K. (2004). Lie Detectors: A Social History. London: McFarland \& Company, Inc., Publishers.

Shaboltas, A. (2017). Forensic and Criminal Psychology in Russia: History of Development and Current State. In P. A. Granhag, R. Bull, A. Shaboltas, E. Dozortseva (Eds.), Psychology and Law in Europe: When West meets East. CRC Press.

Schmitt, N. (2013). The Oxford Handbook of Personnel Assessment and Selection. Oxford Library of Psychology.

Schneider, H. J. (2014). Kriminologie: Ein internationales Handbuch. Berlin: De Gruyter.

Schrenk-Notzing, A. (1897). Suggestion und Erinnerverfälschung im Bertoldprozeß. Leipzig: Barth.

Solnař, V. (1933). František Kafka: O psychobiologickém výzkumu v kriminologii. Právník, $72,517$.

Terman, L. (1916). Selection of Police Patrolmen. Journal of Applied Psychology, 1,11.

Veselá, J. (1928). Obviněný jako předmět trestního řízení a psychologické metody zjištování skutkových okolností. Věstnik Československé společnosti pro trestní právo. Praha.

Vobořil, D., Květoň, P., \& Jelínek, M. (2009). Pohled do Wundtovy laboratoře - 130. výročí založení. Československá psychologie, 6, 612-617. 
von Jagemann, L. H. F. (1839). Über die Mittel zur Unterdrückung der Misbräuche der Untersuchungsbeamten.

von Thun, L. (1836). Die notwendigkeit der moralischen Reform der Gefängnisse mit Hinweisung auf die zur Einführung derselben in einigen Ländern getroffenen Maßregeln beleuchtet. Prag: Borrosch u. Andre.

Wagner, G.H. (1981). William Healy, M.D., Father of the American Child Guidance Movement. Masters thesis: Air Force Institute of Technology Wright-Paterson AFB $\mathrm{OH}$.

Walther, O.A. (1854). Hand-Lexicon der juristischen Literatur des neunzehnten Jahrhunderts. Weimar.

Weiner, D. (1992). Phillippe Pinel's “Memoir on Madness" of December 11, 1794: a fundamental text of modern psychiatry. American Journal of Psychiatry, 149 (6), 725 732 .

Weiner, I., Otto, R. (2014). The Handbook of Forensic Psychology. Wiley.

Weiner, I. B., Hess, A. K. (2006). The Handbook of Forensic Psychology. Hoboken: New Jersey, Wiley.

Wertheimer, M., King, D. B., Peckler, M. A., Raney, S., \& Schaef, R.W. (1992). Carl Jung and Max Wertheimer on a priority issue. Journal of the History of the Behavioral Sciences, 28, 45-56.

Wicks-Nelson, R., Israel, A. (2013). Abnormal Child and Adolescent Psychology with DSM-V Updates. London: Psychology Press.

Wolfram, H. (2018). Forensic Psychology in Germany: Witnessing Crime, 1880-1939. Palgrave Macmillan.

Zoubková, I. a kol. (2018). Aktuální problémy kriminologie. Praha: Policejní akademie České republiky.

\section{Údaje o autorce:}

PhDr. Veronika A. Polišenská, MSc., Ph.D. se zaměřuje na forenzní psychologii. Přednáší na Katedře kriminalistiky a forenzních disciplín Fakulty právních a správních studií Vysoké školy finanční a správní, a.s. V letech 2007 až 2015 působila ve Výkonné radě Evropské federace psychologických asociací. Od roku 2014 je výkonnou místopředsedkyní Unie psychologických asociací ČR.

\section{Kontaktní údaje:}

Adresa: VŠFS, Estonská 500, 10100 Praha 10

E-mail: e-mail: v.polisen@gmail.com

Polišenská, V. A. (2019). Forenzní psychologie v české psychologické literatuře - náhled do historie do začátku druhé světové války. E-psychologie, 13(1), 32-47. https://doi.org/10.29364/epsy.337 